\title{
BOOSTING TECHNOLOGICAL INNOVATION AND INNOVATION CULTURE FROM AN IDEA GENERATION PROGRAM: THE EXPERIENCE OF A BRAZILIAN BANK
}

\author{
IMPULSIONANDO A INOVAÇÃO TECNOLÓGICA E A CULTURA DE INOVAÇÃO A PARTIR DE UM PROGRAMA \\ DE GERAÇÃO DE IDEIAS: A EXPERIÊNCIA DE UM BANCO BRASILEIRO
}

IMPULSAR LA INNOVACIÓN TECNOLÓGICA Y LA CULTURA DE LA INNOVACIÓN A PARTIR DE UN PROGRAMA DE GENERACIÓN DE IDEAS: LA EXPERIENCIA DE UM BANCO BRASILEÑO

\section{Lucas Makoto Conchon Ida ${ }^{1}$ Cleonir Tumelero ${ }^{2}$}

\section{Cite as - American Psychological Association (APA)}

Ida, L. M. C., \& Tumelero, C. (2021, Sept./Dec.). Boosting technological innovation and innovation culture from an idea generation program: the experience of a Brazilian bank. International Journal of Innovation - IJI, São Paulo, 9(3), 474-495. https://doi.org/10.5585/iji.v9i3.19282.

\begin{abstract}
Objective of the study: The objectives of this study were to describe the strategy and the innovation results from an idea generation program (IGP) of a Brazilian bank.

Methodology: The study is predominantly descriptive; the method is the in-depth case study, and the data analysis was performed through content analysis.

Originality/Relevance: The IGP's implementation stage is critical due to the need for financial resources, people, and time. An IGP can generate not only incremental technological innovations but also boost the innovation culture. Innovations developed from an IGP can be effective in facing competition from fintechs and digital transformation.

Main results: The IGP's strategy is well-founded, as the result of 14 years of experience. However, there is still no clear strategy for measuring the impact of the implemented innovations. The IGP boosted both incremental technological (product, services, and process) and innovation culture. It has generated financial and non-financial results, and it predominantly follows the eastern model, recognizing employees' ideas with non-financial rewards.

Theoretical/methodological contributions: An IGP is designable in three main stages: ideation, in which all employees can participate, giving ideas for solving the problems indicated by the boards; selection, when a selection board chooses the ideas with the most significant potential for implementation and generating results; and implementation, when the selected ideas are transformed into innovations.

Social /management contributions: A bank's idea generation program is effective to boost technological innovation and innovation culture, which allow to face the fintechs and other essential players in the financial market, as well as to promote internal engagement and manage digital transformation, and deal with the VUCA (volatility, uncertainty, complexity, and ambiguity) scenario.
\end{abstract}

Keywords: Bank. Innovation culture. Idea Generation Program. Ideas implementation. Incremental innovation. Technological innovation.

\section{Resumo}

Objetivos do estudo: Os objetivos deste estudo foram descrever a estratégia e os resultados de inovação de um programa de geração de ideias (IGP) de um banco brasileiro.

\footnotetext{
1'Master's in Business Administration, Business School - Positivo University. Curitiba - Paraná, Brazil. lucas_ida@yahoo.com.br

2 Ph.D. in Business Administration, Business School - Positivo University. Curitiba - Paraná, Brazil. cleonir.tumelero@gmail.com
} 
Metodologia: $\mathrm{O}$ estudo é predominantemente descritivo; o método é o estudo de caso em profundidade e a análise dos dados foi realizada por meio da análise de conteúdo.

Originalidade/Relevância: A fase de implementação do PGI é a mais crítica, devido à necessidade de recursos financeiros, pessoas e tempo. Um PGI é capaz de gerar não apenas inovações tecnológicas incrementais, mas também impulsionar a cultura de inovação. As inovações geradas a partir de um IGP podem ser eficazes para enfrentar a concorrência das fintechs e a transformação digital.

Principais resultados: A estratégia do PGI é bem fundamentada, fruto de 14 anos de experiência, porém, ainda não há uma estratégia clara para mensurar o resultado das inovações implementadas. $\mathrm{O}$ PGI foi eficaz para impulsionar tanto a inovação tecnológica incremental (produto, serviços e processo) quanto a cultura de inovação, gerou resultados financeiros e não financeiros, e segue predominantemente o modelo oriental, reconhecendo as ideias dos funcionários com recompensas não financeiras.

Contribuições teóricas/metodológicas: Um PGI pode ser desenvolvido em três etapas principais: a ideação, da qual todos os funcionários podem participar, dando ideias para a solução dos problemas apontados pelas diretorias; seleção, quando um júri escolhe as ideias com maior potencial de implementação e geração de resultados; e implementação, quando as ideias selecionadas serão transformadas em inovações.

Contribuições sociais/para a gestão: O programa de geração de ideias de um banco é eficaz para impulsionar a inovação tecnológica e a cultura de inovação, o que permite enfrentar as fintechs e outros importantes players do mercado financeiro, bem como promover o engajamento interno e gerenciar a transformação digital, e lidar com o cenário VUCA (volatilidade, incerteza, complexidade e ambiguidade).

Palavras-chave: Banco. Cultura de inovação. Programa de geração de ideias. Implementação de ideias. Inovação incremental. Inovação tecnológica.

\section{Resumen}

Objetivo del estudio: Los objetivos de este estudio fueron describir la estrategia de innovación y los resultados de un programa de generación de ideas (PGI) de un banco brasileño.

Metodología: El estudio es predominantemente descriptivo; el método es el estudio de caso en profundidad y el análisis de datos se realizó a través del análisis de contenido.

Originalidad / Relevancia: La fase de implementación de PGI es la más crítica, debido a la necesidad de recursos financieros, personas y tiempo. Un PGI puede generar no solo innovaciones tecnológicas incrementales, sino también impulsar la cultura de la innovación. Las innovaciones generadas a partir de un PGI pueden ser efectivas para enfrentar la competencia de las fintechs y la transformación digital. Resultados principales: La estratégia del PGI está bien fundamentada, resultado de 14 años de experiencia, sin embargo, aún no existe una estrategia clara para medir el resultado de las innovaciones implementadas. El PGI fue eficaz en impulsar tanto la innovación tecnológica incremental (productos, servicios y procesos) como la cultura de la innovación, generó resultados tanto financieros como no financieros, y sigue predominantemente el modelo oriental, reconociendo las ideas de los empleados con recompensas no financieras.

Contribuiciones teóricas / metodológicas: Un PGI se puede desarrollar en tres etapas principales: ideación, en la que pueden participar todos los empleados, dando ideas para la solución de los problemas señalados por las juntas; selección, cuando un jurado elige las ideas con mayor potencial de implementación y generación de resultados; e implementación, cuando las ideas seleccionadas se transformarán en innovaciones.

Contribuiciones sociales / de gestión: El programa de generación de ideas de un banco es efectivo para impulsar la innovación tecnológica y cultural, lo que le permite enfrentar a fintechs y otros actores importantes del mercado financiero, así como promover el compromiso interno y gestionar la transformación digital, y enfrentar el escenario VUCA (volatilidad, incertidumbre, complejidad y ambigüedad.

Palabras clave: Banco. Cultura de la innovación. Programa de generación de ideas. Implementación de ideas. Innovación incremental. Innovación tecnológica. 


\section{Introduction}

The world is going through rapid technological, social, and economic changes, creating a volatile, unstable, complex, and ambiguous (VUCA) scenario. The new normal is rapidly changing in the business environment, business models are becoming obsolete, and companies need to adapt quickly (Lawrence, 2013). Companies need to innovate to remain competitive and survive in such a dynamic and unpredictable market (Quandt, Silva, Ferraresi \& Frega, 2014; Tidd \& Bessant, 2015). This environment requires an agile and adaptive behavior of organizations, once the VUCA scenario creates opportunities and challenges that the company must be prepared to take advantage of it and stand before its competitors (Mack, Khare, Krämer \& Burgartz, 2015).

The changing environment makes the companies better adaptable to survive and growin the market. Adaptation can take place through the development of new products, production processes, and forms of commercialization, in addition to organizational changes (Nelson \& Winter, 1982). Quandt et al. (2014), Tidd and Bessant (2015), and Barcelos (2016) agree that innovation is an excellent competitive strategy to acquire more consumers. Tidd and Bessant (2015) cite the processes of generating ideas as an innovation strategy. In this sense, a set of systematic innovation processes can give rise to an idea generation program (IGP).

In one IGP, generally, there are the ideation, evaluation, selection, and implementation phases (Quandt et al., 2014). It is recommended that the company make efforts to create a favorable environment (Chandler, Keller \& Lyon, 2000; Menzel, Aaltio \& Ulijn, 2007), and innovative values must be present in the organizational identity (Klein \& Sorra, 1996), to implement innovative ideas. However, there are several barriers and facilitators in implementing innovative ideas in a company. Especially in the implementation phase, there is a need to assess the innovation's risks, since financial resourcesand the organization's structure are used to innovate (Dorow, de Medeiros, de Souza \& Dandolini, 2013).

Although there is a possibility of enhancing innovation through an IGP (Barbieri, Álvares \& Cajazeira, 2009a), such programs need a structure to ensure that the ideas are effectively implemented (Froehlich, 2016). Among the key decisions that can make an IGP a success or failure are the program's structuring, the form of recognition, investment in the best ideas, and awareness of participation (Quandt et al., 2014).

In the ideas implementation phase, common difficulties are the organizational climate and the adjustment to innovative values. The better the organizational environment and the alignmentwith innovative values, the greater the chances of the innovation to be implemented 
(Klein \&Sorra, 1996). Thus, there is a concern about whether the organization will effectively implement the ideas generated from innovation programs. Understandably, the implementation phase imposes a series of challenges oncompanies insofar as they need financial investments, time, people, and planning (Sacramento\& Teixeira, 2014).

Few companies succeed in transforming their employees' creativity into innovative ideas even through innovation processes (Cooper \& Edgett, 2012; Van Dijk \& Van Den Ende, 2002). Evidence is that a considerable part of the ideas generated do not generate results due to these difficulties (Anderson, Potočnik \& Zhou, 2014).

In this line, we highlight the importance of studying the criticality of the implementation phase (Sabri, Micheli \& Nuur, 2018), once without implementation, the previous stages do not generate objective results for the company (Singh, Akbani \& Dhir, 2020). For this reason, it is vital to understand better the implementation phase and the possible innovation results generated from an IGP (Adams, Bessant \& Phelps, 2006).

We also highlight those studies on services innovation have considerably increased (Janssen \& Castaldi, 2018), which suggests the opportunity for more in-depth studies on the innovation process in service companies (Kitsuta \& Quadros, 2019). In particular, innovations in financial services have investigation opportunities (Snyder, Witell, Gustafsson, Fombelle \& Kristensson, 2016), notably considering the digital transformation that banks are undergoing. Due to an accelerated global process of technological adaptation in digitization and digitalization (Perides, de Vasconcellos \& Vasconcellos, 2020).

Given the research opportunities identified, this study seeks to answer the following research question: "How an idea generation program (IGP) influences a bank's innovations?". The objectives of this study are: (i) to describe the strategy of an IGP; and (ii) to identify the innovation results from an IGP.

\section{Theoretical reference framework}

\subsection{Implementation of innovations}

Nelson and Winter (1982), when contributing to the Evolutionary Theory of Innovation (ETI), described a natural economic selection that separates companies that will evolve from those that will be extinct in an environment of significant changes. Organizations that have the most appropriate shape for the environment will prosper, the others will decrease or become extinct (McKelvey, 2016). In the struggle for survival, companies try to create and apply technological innovations and invest in research and development (R\&D), seeking results that 
generate new commercial products or services (Machado, 1998; Marins, 2007; Pessali \& Fernández, 2006).

The Olso Manual (2018, p. 62) describes innovation as:

\begin{abstract}
A new or improved product or business process (or a combination thereof) that differs significantly from the previous products or processes and that has beenmade available to potential users (product) or put into use by the organization(process).
\end{abstract}

The Oslo Manual (2018) names "product innovation" as innovations in products and services and "business process innovation" as innovations in the production of products and services, distribution and logistics, marketing and sales, information and communication systems, management and administration, and or either development of products and business processes. In service innovation, there is usually a relationship with tacit knowledge, sometimes allowing the company to innovate in organizing human resources to manage the knowledge better. Also allowing to implement improvements in customer interfaces, innovate in management techniques, and increase the company's flexibility (Sarkar \& Carvalho, 2006). Dosi, Grazzi, and Moschella (2015) highlight the difference between product and process innovation, comparing types and arguing that product innovation is more important in companies that are not in the service sector. On the other hand, innovation in business processes is prevalent in companies in the service sector (Sarkar \& Carvalho, 2006).

Organizations do invest resources in innovation programs, even if the programs do not always return financial results due to internal factors such as: risk involved to innovation, difficulties in managing a program innovation, the persistence required to wait for the innovation program results, the problem of measuring innovation results and the difficulty in motivating employees to participate in the program (Åmo \& Kolvereid, 2005).

For Tidd and Bessant (2015), one of the main difficulties in managing innovation is its complexity. For this reason, models of innovation processes are created, which are simplifications that allow the visualization of processes that enable innovation management. Frankenberger et al. (2013) show models of innovation processes with well-defined phases, such as ideation, selection, and implementation of ideas. When systematically organized, these models can be called ideas generation programs (IGP). 


\subsection{The idea generation programs}

The transformation of ideas into products placed on the market or processes that are implemented in companies does not happen, most of the time, by chance or by extraordinary ideas (Drucker, 2004). A solution could emerge through a well-structured process, which goes through generating ideas, selecting the best ideas, and implementing these ideas (Froehlich, 2016; Tidd \& Bessant, 2015).

A process, here, is conceptualized as procedures or sequences of routines (Baregheh, Rowley \& Sambrook, 2009). It can also be considered as the systematization of patterns and tools to achieve an objective (Borchardt \& Santos, 2014). The process leads to a trajectory, an ordered sequence of phases that seek to reach a goal when carrying out all the steps proposed and may not be linear and incur several interactions between the steps (Kline \& Rosenberg, 1986).

The innovation processes are not simple, and they implicate in technological and social knowledge to happen. This complexity does not allow for a unique and ideal model of the innovation process to be implemented (Froehlich, 2016; Kline \& Rosenberg, 1986), so the companies have to make many strategic decisions to innovate (Dobni \& Sand, 2018).

IGP are processes used by organizations to generate ideas from multiple sources in order to innovate (Dorow, Dávila, Varvakis \& Vallejos, 2017). For companies concerned with constant innovation, generating many ideas is essential to achieve their goal of innovating (Barbieri, Álvares \& Cajazeira, 2009b).

In addition to the innovations originated by the IGP, there is the company's possibility todevelop additional benefits, such as the expansion of intellectual capital, interdepartmental cooperation, creation of routines to implement innovative ideas, generation of employee's belonging sense, stimulating creativity in the workforce, generating a culture of innovation, learning from mistakes, among others (Åmo, 2005; Du Plessis, 2007; Gołaś, Mazur, Gruszka \& Szafer, 2016).

The programs with the best results generally consider the program's objective, the number of ideas generated, who will be the participants, rewards, program rules, approval of suggestions, and system management (Barbieri, Álvares \& Cajazeira, 2009a). The company also needs to be concerned with the organizational environment that favors innovation to reach better results (Tidd \& Bessant, 2015).

There is an important decision about IGP's rewarding. The programs can have as base remuneration rewards on profit and/or cost reduction to the generator of the idea. The rewarding 
can also be voluntary and based on symbolic and collective prizes, such as job maintenance and profit sharing for all employees (Miguez, 2012).

There is a distinction between what the authors call the western model and the eastern model of IGP. The west model seeks brilliant ideas and usually pays participants of IGP a percentage of the gain that is obtained through the idea in the first year after its implementation, reinforcing individualist and monetarist principles. On the other hand, the eastern model has in its conception the principle that everyone participates in the generation of ideas for the wellbeing of the company, strengthening the sense of team (Barbieri, Álvares\& Cajazeira, 2009b).

It is in the stage of generating ideas that people connect more intensely, relating knowledge and creativity. In this systematic process of developing ideas, it is important to align problems that are still being solved with its strategy. In addition, it is important to have a specific time for this phase, not being too short for the company to capture ideas in quantity and quality (Miguez, 2012).

After the idea generation phase, the company must decide how to select the ideas that will be implemented. Since not all ideas will be used, the filter used by the selection committee, designated by the company that created the IGP, should consider whether the idea is complete and in line with the program's objectives (David, Carvalho \& Penteado, 2011).

There are criteria to be followed in the selection phase to organize ideas according to their potential for generating new products, services, or organizational changes. Suppose the companydoes not have a clear and logical system for selecting ideas. In that case, many good ideas may fail when implemented, which would make the company fail to gain the benefits that those ideas would generate, and participants in the IGP may fail to believe in the efficiency of the program, makingit fall into disrepute (Dorow et al., 2017).

When ideas are in the implementation phase, there is a possibility that barriers will prevent innovation from happening. They can be economic, technical deficiencies, information, national innovation system, internal problems of companies, or regulation (Kühl \& Cunha, 2013; Mussi \& Spuldaro, 2008). Other barriers to innovation might be: the error aversion culture; the possibility of financial loss in investment in innovation; the difficulty in dealing with the change process that innovation generates; the problem of negotiating with the company's top echelons to sponsor the innovation; the absence of the creation of an environment conducive to innovation; the immediacy of results; among others (Feldens, Maccari \& Garcez, 2012). 
There is an influence of leaders in the stage of ideas implementation to overcome the barriers that may arise, as well from the marketing sector, which generally studies the financial viability of implementing the idea, as from management, which should welcome innovation for practical use in the organization (Adams, Bessant \& Phelps, 2006).

Only implemented ideas are transformed into innovation and can generate results for the company. Regarding the potential outcomes of innovation, Gault (2018) indicates that measurement should start with the correct definition of innovation to know what should be measured. As previously seen, there are several innovation concepts, so it remains for the organization to decide a clear definition of what innovation is to measure its results appropriately.

The Oslo Manual (2018) refers to ways of measuring innovation results. As innovation seems like economic activity, it is clear that it has value to be measured, but there is no way to guarantee the results since they are uncertain. One of the Oslo Manual (2018) suggestions is to verify the increase in the gross financial value generated after implementing an innovation. Since the results can benefit both the company that implemented it and other interested parties, the innovation results are only adequately measurable when the outcomes are analyzed after some time. Thus, even the Oslo Manual (2018) reinforcesthat not all innovation measurement strategies are mature enough, suggesting the need formore research and experimentation on ways to measure innovation results.

\section{Methodology}

The study is predominantly descriptive because it "specifies properties, characteristics and important traits of a phenomenon" (Sampieri, Collado \& Lucio, 2013, p.102). The study also presents exploratory nuances, as it seeks to investigate a phenomenon still under theoretical construction (Sampieri, Collado \& Lucio, 2013). The method defined for the present investigation is the single case study, which describes or explains the events of one case based on quantitative or qualitative data, usually using field research (Yin, 2017).

The object of this single case study is an idea generation program (IGP) of a Brazilian bank. Yin (2017) describes that for a particular case to be chosen, that case must stand out before others. In this line, the following singularities were considered for the definition of the unit of analysis: is the only program for generating ideas with public information among the five largest Brazilian banks; is relatively mature, as it has been running for fourteen years, with six editions made; presents concrete results of innovation since its first edition; received around 
20 thousand ideas from the bank's employees; stands out in reports from business magazines; is linked to the bank's corporate strategy of innovation; the organization studied received several awards, such as: E-finance Award, in which it won twenty-one categories due to a series of innovations; Corporate Innovation Award, at the Fall Summit event, held by the Plug and Play Tech Center in SiliconValley.

The technique chosen for the primary data collection was the semi-structured interview that followed a research script and a questionnaire. This research took the following steps to create the data collection instrument: three rounds of validation with researchers from a research group on innovation and entrepreneurship in a Brazilian postgraduate program in Business Management course; validation with market specialists who work with innovation and people management; a round of pre-tests with employees of the bank object of this study. Nine interviews were carried out, with an average of 27 minutes, with data saturation observation after the eighth interview. And, finally, professionals of three functions were interviewed: Creator, Idea Generation Program Manager, and Implementer.

In addition to the interviews, internal company documents about the IGP were obtained as secondary data, which intended to contextualize the IGP, demonstrating the evolution and changes that occurred in the program, also being part of the research triangulation with the primary data obtained.

Content analyses carried the analyses data in the search for systematically discover the core of the content of the messages to the point of allowing inferences from the interviews and documentary sources. The content analysis was intended to overcome uncertainties about the information received in the data collection and enrich the reading of the data from the interviews and the documentary analysis (Bardin, 2011).

The steps described by Bardin (2011) were followed: pre-analysis, which organizes the data collected in the interviews; exploration of the material, when codifications are performed, using sections of the collected material; and the treatment of results, inferences, and interpretation, comparing the categories generated in the previous phase and resulting in a final analysis.

\section{Results}

The first objective of this study is to describe the strategy of an IGP. In this systematic process of generating ideas, it is important to align the problems to be solved with the company's strategy, giving freedom for all employees to participate with ideas that create radical 
innovations. In the IGP study, the deadline for the ideation phase is 45 days to enable even employees on vacation to participate.

The IGP uses as a selection committee a board formed by members of the boards that launched challenges for the program. The phase of implementing innovations in the IGP seems to be one of the most critical, as mentioned by Anderson, Potočnik, and Zhou (2014) and Kühl and Cunha (2013), and, for this reason, was the focus of this research. The main stages perceived by the interviewees of the studied IGP are ideation, selection, and implementation, as shown in Figure 1.

\section{Figure 1}

\section{Phases of the Idea Generation Program}

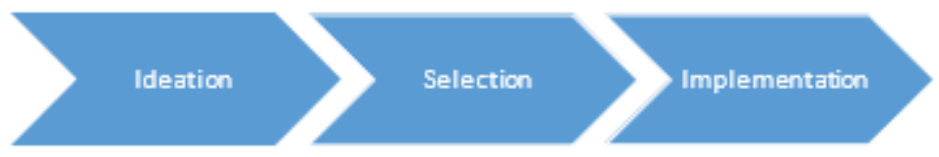

Source: Survey data.

In the studied program, the implementation phase had a contribution of an employee designated as 'implementer'. This employee, from each board that launched challenges for the IGP, received the selected ideas and made them become an innovation.

\footnotetext{
"We have the challenge $x$, and I want to open up for ideas in IGP. Then, the committees selected the ideas to be implemented, and the figure of the implementer there was created, who would be the godfather employee of that idea to implement it." (Implementer 1)
}

The interviewees reveal that the objectives of the IGP are to foster a culture of innovation, engage employees, capture ideas from all employees and innovate by generating solutions for customers and the organization. These objectives guide IGP's strategic planning decisions. Strategic decisions are about: having a theme orientation or having an open theme for any idea, who will be able to participate in the program, what will be the rewards, what will be the phases, how the regulation will be, and how to manage the system.

The objective of fostering a culture of innovation in the company meets Van Dijk and Van den Ende (2002) and Keles and Batal (2017). They say that the culture of innovation is essential for the success of a program for generating ideas, especially in the ideation phase. The findings are also aligned with Klein and Sorra (1996), who complement that company's adequacy to the culture of innovation is important in the innovation implementation phase, and 
Froehlich (2016), who says that the implementation of an IGP can contribute to the formation of a culture of innovation in the company.

The company's decision to create challenges for IGP is in line with Tushman (1977), who cites the concern to mobilize the management areas in a coordinated way so that the idea generation program is successful.

The strategic decision on who can participate in the IGP considers the following options: restricted to employees on the boards, all employees of the organization, or people outside the company. In the case of the IGP under study, interviewees, managers, creators, and implementers mentioned that the program allows the participation of all employees, including incentives for everyone to participate.

This choice enhances the number of ideas generated and diversifies the points of view oneach problem that the organization wants to solve through the IGP. Receiving ideas from all employees creates difficulty in managing the data received but encourages a culture of innovation throughout the organization and generates greater employee engagement. Tigre (2014) addressed the encouragement of participation by all employees and, on the board or not, which is also a relevant point for Quandt et al. (2014). This concern of the company was noticed when thinking about the strategy of the idea generation program.

There are two possibilities known in the literature about the rewards of idea generation programs. Miguez (2012) says that the employees rewarding, who participate in the idea generation program, can be based on financial remuneration or the valorization of voluntary participation, with symbolic awards.

Instead of financial awards, the organization rewarded the best ideas implemented with symbolic prizes such as travel miles and airline tickets. In addition, the rewarded employees cite the importance of recognition by peers and superiors, visibility through internal communication, the inclusion of the award in the functional curriculum, and the incentive to participate in the program to have the opportunity to be awarded. There is a valorization of implemented ideas that effectively generate innovation in the company.

"It had a recognition, it divulged, it put the first ones on the intranet, the corporate TV broadcasted live. It had the award for the director, for the vice-president, it had a whole environment that Ifound extremely interesting. It had both intrinsic and extrinsic recognition, you know, and that motivated me to think about the bank every day. " (Creator 3)

There is evidence that the idea generation program under study is prone to the eastern model in terms of rewards since the awards have been symbolic. It is possible to perceive that 
the recognition before peers and the positive visibility of the superiors is vital for the participants of the idea generation program, in line with what the Asian model already mentioned suggests.

Additionally, the bank needs to decide how to operationalize the IGP, the number of stages to be defined, the phases division, the amount of time each step will take, and who will execute each part of this innovation process.

As secondary data, a summary of the regulation of the idea generation program (Table 1) of the 2018 version is presented to complement the interviewees' perception about the result of the company's strategic decisions on the IGP.

\section{Table 1}

Summary of IGP's regulation

\begin{tabular}{|c|c|}
\hline Topics & Description \\
\hline Objectives & $\begin{array}{l}\text { Each program's objective is described in detail, citing the motivation to the culture of } \\
\text { innovation, meeting the four-year strategic goals, among others. }\end{array}$ \\
\hline $\begin{array}{l}\text { General } \\
\text { description }\end{array}$ & $\begin{array}{l}\text { Informs the voluntary nature of participation in the program, the forms of participation, who } \\
\text { will be part of the idea-selecting committees, and who is the target audience who can suggest } \\
\text { ideas }\end{array}$ \\
\hline $\begin{array}{l}\text { Campaign } \\
\text { stages }\end{array}$ & $\begin{array}{l}\text { Describes the stages of collecting ideas, selecting the best ideas, detailing, improving, } \\
\text { developing, and implementing the ideas. On conduction matter, the units of the board } \\
\text { propose the challenges to be launched to receive ideas and describe how the ideas will be } \\
\text { selected and implemented. }\end{array}$ \\
\hline Award & Indicates the number of ideas and implementers to be awarded \\
\hline $\begin{array}{l}\text { Awards and } \\
\text { recognition }\end{array}$ & Describe what non-financial awards will be, such as travel and points in mileage programs \\
\hline $\begin{array}{l}\text { Complementary } \\
\text { provisions }\end{array}$ & $\begin{array}{l}\text { Describes the inclusion in the functional curriculum of employees who have ideas recognized } \\
\text { in the program }\end{array}$ \\
\hline Schedule & $\begin{array}{l}\text { Describes the complete schedule of the edition of the idea generation program, from the } \\
\text { collection of ideas to the award and recognition event }\end{array}$ \\
\hline
\end{tabular}

Source: Secondary data.

It is noteworthy that the interviewees' perception of the objectives, the target audience for participation, the award, and the IGP phases were adherent to the program's regulations.

The disclosure of the regulation of the idea generation program under study is an essential point for its success. Barbieri, Álvares, and Cajazeira (2009a) agree that it is important for an IGP to succeed and the decisions made by the studied bank.

The board responsible for the IGP carried out the system management used for employees to input their ideas. In the first editions, management was manual, submitting printed forms and lettering ideas. With the evolution of the IGP, management started take place on a 
digital platform, with the possibility of better managing the ideas sent, including joining similar ideas and revisiting the ideas in an opportune time (ideas garage).

It was perceived by the interviewees the importance of making the platform available for receiving ideas for periods of approximately 45 days to make the participation of all employees possible. In addition, a framework was used to classify ideas by their degree of innovation, incremental or radical.

System management is an essential part of the IGP, as it can facilitate or generate barriers to innovation in the company. A lean team of three employees was responsible for making strategic decisions of the studied organization on managing the IGP. They were located at the company's headquarters, in the digital business directorate.

Note that the IGP studied is predominantly of the eastern model, recognizing employees with non-financial rewards and originating, mainly, incremental innovations in improvements in the company's processes, products, and services.

The second objective of this study is to identify the innovation results from an IGP. The implemented innovations through the bank's idea generation program can be classified into the following types: product innovation - products and services, plus innovation in business processes -, innovation in distribution and logistics, innovation in administration and management. Both types of innovations are technological in products/services and processes, and are possible by the digital transformation underway in the investigated bank. The implemented innovations follow the Oslo Manual (2018) classification for technological innovations of product and process.

The main product innovation identified was the creation of a credit and debit card with exclusive benefits to encourage consumption in the city, where people received their wages to promote local commerce. The innovation in services observed was creating a new way for the customer to renegotiate debts with the bank, without the possible constraint of face-to-face service, allowing the customer to make an offer to settle the debt through App or internet banking.

The innovation in distribution and logistics observed was the creation of the possibility to inhibit the sending of paper reports to a bank branch that did not use them, generating paper savings and consequent environmental sustainability, and optimizing the company's logistical efficiency. Employees observed innovation in administration and management in creating a new form of training through a video uploading platform that enabled the company's multiplication of knowledge and better knowledge management. 
The innovations observed were predominantly incremental, as expected by the IGP format under study. However, there was difficulty in measuring the results of innovations, one of the perceived barriers to innovation was, precisely, the lack of indicators of innovation results, a failure of innovation management. Seshadri and Tripathy (2006) already predicted this difficulty in measuring the results of innovation.

Some results were measured, such as the financial results of one of the implemented ideas that dealt with debt renegotiation through internet banking. The perceived result was approximately five billion Reais, an expressive value in the financial market in which the company studied is inserted.

"The implemented idea originated in the IGP is already in almost 5 billion Reais of assets renegotiated bythe bank." (Manager 2)

Other implemented ideas may have generated financial results. However, they were not measured, as mentioned in the inhibition of the emission of reports that were discarded when they reached the recipient, which is an innovation in distribution and logistics. Some innovations may have greater complexity to measure the results, as in the case of the city that was benefited with credit cards so that the money received by the population circulated in local commerce, instead of being spent in the commerce of neighboring cities, which is an innovation in product/service.

IGP managers mentioned that one of the expected results of the innovations was to encourage a culture of innovation in the company. In this case, the IGP impacted approximately $40 \%$ of the company's employees, which potentially fosters a culture of innovation among employees.

A strategic failure was observed regarding the lack of measurement of the results of innovations originated by the IGP. Expected outcome both for the IGP employees' participants and for the company's top management. Employees could perceive the results of their participation, and the company's management could verify if the IGP generates a financial return or if the costs to maintain the IGP are outweighed by the returns of the innovations originated by the program.

\footnotetext{
"In the course of the idea being implemented, we take the test, et cetera, there was no way for us to measure it." (Manager 3)
} 
Although at least the financial value originated from one innovation was measured, what compensated the continuation of the IGP, it is noticed that there is a need to systematize the measurement of the results of innovations for the company to know if it pays to continue the IGP. This concern meets the Oslo Manual (2018) and Brattström et al. (2018), who claim that innovation as an economic activity engages firms and, therefore, needs to have its results measured to know if the opportunity cost to innovate is being advantageous for the company.

These quotes demonstrate the difficulty perceived by the interviewees when asked about the results of the implemented innovations. Such outcomes in the studied company confirm what Seshadri and Tripathy (2006) said about the difficulty of measuring the results of innovations.

\section{Conclusions}

This study sought to answer the following question: "How an Idea Generation Program (IGP) influences a bank's innovations?". The IGP was strategically designed to take place in three main stages: ideation, in which all employees can participate, giving ideas for solving the problems indicated by the boards; selection, when a selection board chooses the ideas with the most significant potential for implementation and generating results; and implementation, when the selected ideas will be transformed into innovation by the implementers of each board.

Our first conclusion is that the creation and maintenance strategy is an important part of the success of an idea generation program. The search for the improvement of the idea generation program to face the changes in the world VUCA (volatility, uncertainty, complexity, and ambiguity) is part of the strategic planning of the investigated bank.

We also concluded that an IGP's strategy must consider decisions about the stages, participants, selectors, amount invested, deadlines for each phase, rules, rewards, and performance measurement. Once we notice the performance measurement is precisely one of the primary IGP's failure.

Such decisions can make the program's existence feasible and encourage greater participation in future editions, or they can generate discredit among employees and lead the program to discontinuity.

Froehlich (2016) already predicted that the decisions to be made about an IGP are complexand without perfect models. Cooper (1990), Giones, Brem, and Berger (2019) expected that there is no way to simplify the process for simple, orderly phases. Sarkar and Carvalho (2006) said that the strategy of the idea generation program must be flexible and adaptable, as 
well asinnovation. Therefore, except for the measurement performance of the implemented innovations, we conclude the IGP's strategic decisions were correctly taken when adopting a model more like the eastern one. The east model tends to value the group and encourage the participation of all, unlike the western model, which has a greater focus on financial reward.

We concluded that the implementation phase of the ideas originated through an IGP is the most critical, and this is due to the need to provide financial resources, people, and time at this stage of the IGP. When it comes to investment, it is important to emphasize that the risk of investing resources is inherent to the innovation process, given that the expected results may not return within the defined period.

The authors who dealt with the implementation stage of the idea generation program, such as Du Plessis (2007), Hallstedt, Thompson and Lindahl (2013), Klein and Sorra (1996), and Kühl and Cunha (2013), were correct concerning the criticality of the implementation phase for the success of innovation in organizations. There were barriers in the implementation stage regarding financial investment, people, time, coordination between company areas, among other difficulties, also in agreement with Sacramento and Teixeira (2014).

However, the lack of financial investment and previous allocation of resources for the ideas to be implemented is a weak point of the investigated IGP which allocated no IT hours specifically to develop originated ideas. Furthermore, the creators did not have a decisive participation in implementing their ideas, and there was notime available for the implementers to invest in the ideas selected by their board. The findings confirm contributions by Miguez (2012), who mentions that the lack of these resources can limit innovation in the company.

Implementing innovation through idea generation programs is complex. However, it can generate expressive results for the organization that intends to allow all employees to solve complex problems. Although the results of the implemented innovations are difficult to measure, the innovations originated in the IGP are perceived by the employees, which is already a result achieved on the innovation culture.

As Borchardt and Santos (2014) described, the measurement of the results of the innovations generated through the studied idea generation program is not effective since the interviewees do not have information about the result of the implemented innovations. About the financial results, there was a measurement of a debt renegotiation innovation through channels other than face-to-face, which increases the time of the survey generated results of approximately five billion Reais. 
The lack of indicators for measuring innovation results was apparent. In these points, the research was confirmatory with the basic theory, suggesting that there are difficulties in this innovation area, as Haldma, Näsi, Saunila, and Ukko (2012) said.

The study verified the generation of financial results for the innovations implemented from the IGP. However, the research also found the incentive to innovation culture to be one of the main results of the understudied IGP. To face the fintechs and other important players in the financial market, the bank under study sought to foster a culture of innovation, which seemed to be a wise strategic decision, to generate innovations, not only in specific innovation events continuously. The previous allows us to conclude that the results generated by the innovations implemented from the IGP are direct, financial, and indirect, of incentive to the culture of innovation. In the end, the IGP effectively boosted both incremental technological (products, process, and services) and innovation culture.

One of the main expected and even declared results in the IGP standard is promoting an innovation culture in the company. In general, the authors treat the culture of innovation as a means to innovate, as suggested by Van Dijk and Van den Ende (2002) and Klein and Sorra (1996). Froehlich (2016) adds that the IGP can contribute to the formation of a culture of innovation. However, the literature does not report fostering the culture of innovation as one of the main objectives of an IGP. Therefore, this study initially concluded that support for the culture of innovation could be a strategic objective of an IGP.

We describe methodological research limitations, such as the choice of participants and the respective unit of analysis. There are also theoretical limitations regarding the full exploration of ideas generation programs with a series of synonyms in the literature. As a suggestion for future research, multiple case studies are indicated in companies with idea generation programs inserted in different sectors of the economy. Another direction would be mixed research, with a quantitative and qualitative approach to the results of innovations generated in companies in the service sector. Finally, it is suggested that studies investigate the use of information technologies, such as Big Data, Analytics, and Artificial Intelligence, to support the management of idea generation programs.

\section{References}

Adams, R., Bessant, J., \& Phelps, R. (2006). Innovation management measurement: A review. International journal of management reviews, 8(1), 21-47. https://doi.org/10.1111/j.1468-2370.2006.00119.x 
Åmo, B. W. (2005). Employee innovation behavior. Ph.D. Thesis (Doctor Oeconomia) - Bodø Graduate School of Business, Norway.

Anderson, N., Potočnik, K., \& Zhou, J. (2014). Innovation and creativity in organizations: A state-of-the-science review, prospective commentary, and guiding framework. Journal of management, 40(5), 1297-1333. https://doi.org/10.1177\%2F0149206314527128

Barbieri, J. C., Álvares, A. C. T., \& Cajazeira, J. E. R. (2009). Gestão de ideias para inovação contínua. Brazil. Bookman Editora.

Barbieri, J. C., Álvares, A. C. T., \& Cajazeira, J. E. R. (2009b). Geração de ideias para inovações: estudos de casos e novas abordagens. Revista Gestão Industrial, 5(3). https://doi.org/10.3895/S1808-04482009000300001

Barcelos, R. (2017). A dinâmica das capacidades-elementos para a gestão estratégia à luz da teoria evolucionária. Gestão e Sociedade, 11(30), 1934-1962. https://doi.org/10.21171/ges.v11i30.2159

Bardin, L. (2011). Análise de Conteúdo. São Paulo, SP: Edições 70.

Baregheh, A., Rowley, J., \& Sambrook, S. (2009). Towards a multidisciplinary definition of innovation. Management decision, 47(8),1323-1339. https://doi.org/10.1108/00251740910984578

Borchardt, P., \& dos Santos, G. V. (2014). Gestão de ideias para inovação: transformando a criatividade em soluções práticas. RAI Revista de Administração e Inovação, 11(1), 203-237. https://doi.org/10.5773/rai.v11i1.1185

Brattström, A., Frishammar, J., Richtnér, A., Pflueger, D. (2018). Can innovation be measured? A framework of how measurement of innovation engages attention in firms. Journal of Engineering and Technology Management, 48, 64-75. https://doi.org/10.1016/j.jengtecman.2018.04.003

Chandler, G. N., Keller, C., \& Lyon, D. W. (2000). Unraveling the determinants and consequences of an innovation-supportive organizational culture. Entrepreneurship theory and practice, 25(1), 59-76. https://doi.org/10.1177\%2F104225870002500106

Cooper, R. G. (1990). Stage-gate systems: a new tool for managing new products. Business horizons, 33(3), 44-54. https://citeseerx.ist.psu.edu/viewdoc/download?doi=10.1.1.474.1777\&rep=rep1\&type $=\mathrm{pdf}$

Cooper, R. G., \& Edgett, S. J. (2012). Best practices in the idea-to-launch process and its governance. Research-Technology Management, 55(2), 43-54. https://doi.org/10.5437/08956308X5502022

David, D. E. H., Carvalho, H. G. D., \& Penteado, R. S. (2011). Gestão de ideias. Curitiba, PR: Aymará. http://repositorio.utfpr.edu.br/jspui/handle/1/2058 
Dobni, C. B., \& Sand, C. (2018). Strategy shift: Integrating strategy and the firm's capability to innovate. Business Horizons, 61(5), 797-808. https://doi.org/10.1016/j.bushor.2018.06.002

Dorow, P. F., de Medeiros, C., de Souza, J. A., \& Dandolini, G. A. (2013). Barreiras e facilitadores para a geração de ideias. Revista Eletrônica de Estratégia \& Negócios, 6(3), 105-124. https://pdfs.semanticscholar.org/ee7f/75538f4fc00dae9ddb124cd9613195bc1851.pdf

Dorow, P., Dávila, G., Varvakis, G., \& Vallejos, R. (2015). Generation of ideas, ideation and idea management. Navus-Revista de Gestão e Tecnologia, 5(2), 51-59. https://dialnet.unirioja.es/descarga/articulo/5168663.pdf

Dosi, G., Grazzi, M., \& Moschella, D. (2015). Technology and costs in international competitiveness: from countries and sectors to firms. Research policy, 44(10), 17951814. https://doi.org/10.1016/j.respol.2015.05.012

Drucker, P. (2004). La disciplina de la innovación. Harvard business review, 82(8), 3-7. https://www.academia.edu/download/34744903/_the_discipline_of_innovation.pdf

Du Plessis, M. (2007). The role of knowledge management in innovation. Journal of knowledge management, 11(4), 20-29. https://doi.org/10.1108/13673270710762684

Feldens, M. A., Maccari, E. A., \& Garcez, M. P. (2012). Barreiras para a inovação em produtos nas pequenas e médias empresas de tecnologia no Brasil. BBR-Brazilian Business Review, 9(3),1-24. https://www.redalyc.org/pdf/1230/123023629001.pdf

Frankenberger, K., Weiblen, T., Csik, M., \& Gassmann, O. (2013). The 4I-framework of business model innovation: A structured view on process phases and challenges. Internationaljournal of product development, 18(3-4), 249-273. http://dx.doi.org/10.1504/IJPD.2013.055012

Froehlich, C. (2016). O programa de ideias para inovação em uma empresa do segmento químico. Revista de Administração IMED, 6(2), 191-205. https://doi.org/10.18256/2237-7956/raimed.v6n2p191-205

Gault, F. (2018). Defining and measuring innovation in all sectors of the economy. Research policy, 47(3), 617-622. https://doi.org/10.1016/j.respol.2018.01.007

Giones, F., Brem, A., \& Berger, A. (2019). Strategic decisions in turbulent times: Lessons from the energy industry. Business Horizons, 62(2), 215-225. https://doi.org/10.1016/j.bushor.2018.11.003

Gołaś, H., Mazur, A., Gruszka, J., \& Szafer, P. (2016, August). Application of the suggestion system in the improvement of the production process and product quality control. In IOP Conference Series: Materials Science and Engineering (Vol. 145, No. 6, p. 062005). IOP Publishing. https://doi.org/10.1088/1757-899X/145/6/062005 
Haldma, T., Näsi, S., Grossi, G., Saunila, M., \& Ukko, J. (2012). A conceptual framework for the measurement of innovation capability and its effects. Baltic Journal of Management, 7(7),355-375. https://doi.org/10.1108/17465261211272139

Hallstedt, S. I., Thompson, A. W., \& Lindahl, P. (2013). Key elements for implementing a strategic sustainability perspective in the product innovation process. Journal of Cleaner Production, 51, 277-288. https://doi.org/10.1016/j.jclepro.2013.01.043

Janssen, M. J., \& Castaldi, C. (2018). Services, innovation, capabilities, and policy: Toward a synthesis and beyond. Science and Public Policy, 45(6), 863-874. https://doi.org/10.1093/scipol/scy017

Keles, O., \& Battal, T. (2017). A model for innovation culture management in organizations (IVALUE 7). International Journal of Innovation, 5(3), 361-374. http://www.redalyc.org/articulo.oa?id=499151573007

Kitsuta, C. M., \& Quadros, R. (2019). Gestão da Inovação em empresas brasileiras de serviços de tecnologia da informação: modelos de inovação planejada, de aplicação rápida e de inovaçãodeliberada a posteriori. Cadernos EBAPE. BR, 17, 1048-1061. https://doi.org/10.1590/1679-395174440

Klein, K. J., \& Sorra, J. S. (1996). The challenge of innovation implementation. Academy of management review, 21(4), 1055-1080. https://doi.org/10.5465/amr.1996.9704071863

Rosenberg, N., \& Landau, R. (Eds.). (1986). The Positive sum strategy: harnessing technology for economic growth. Washington, DC: National Academies Press.

Kühl, M. R., \& da Cunha, J. C. (2013). Obstáculos à implementação de inovações no Brasil: como diferentes empresas percebem sua importância. BBR-Brazilian Business Review, 10(2), 1-25. https://www.redalyc.org/pdf/1230/123027923001.pdf

Lawrence, K. (2013). Developing leaders in a VUCA environment. UNC Executive Development, 1-15. http://www.cfmt.it/sites/default/files/af/materiali/Developingleaders-in-a-vuca-environment.pdf

Machado, R. T. M. (1998). Fundamentos sobre o estudo da dinâmica das inovações no agribusiness. Revista de Administração Contemporânea, 2(2), 127-141. https://www.scielo.br/j/rac/a/4gFwmwsgM9NMYn3sgVphfMM/?format=pdf\&lang=p $\mathrm{t}$

Mack, O., Khare, A., Krämer, A., \& Burgartz, T. (Eds.). (2015). Managing in a VUCA World. Berlin, Germany: Springer. https://doi.org/10.1007/978-3-319-16889-0

McKelvey, M. (2016). Firms navigating through innovation spaces: a conceptualization of how firms search and perceive technological, market and productive opportunities globally. Journalof evolutionary economics, 26(4), 785-802. https://doi.org/10.1007/s00191016-0478-0 
Menzel, H. C., Aaltio, I., \& Ulijn, J. M. (2007). On the way to creativity: Engineers as intrapreneurs in organizations. Technovation, 27(12), 732-743. https://doi.org/10.1016/j.technovation.2007.05.004

Miguez, V. B. (2012). Uma abordagem de geração de ideias para o processo de inovação (Master's Thesis). Universidade Federal de Santa Catarina, Florianópolis, Brazil. http://repositorio.ufsc.br/xmlui/handle/123456789/100942

Mussi, F. B., \& Spuldaro, J. D. (2008). Barreiras à inovação e a contribuição da perspectiva institucional: um estudo de múltiplos casos. INMR-Innovation \& Management Review, 5(1), 36-52. https://www.revistas.usp.br/rai/article/download/79099/83171

Nelson, R. R., \& Winter, S. G. (2009). An evolutionary theory of economic change. Cambridge, MA: Harvard University Press.

Organisation for Economic Co-operation and Development., \& Statistical Office of the European Communities (2018), Oslo Manual 2018: Guidelines for Collecting, Reporting and Using Data on Innovation (4th ed.). The Measurement of Scientific, Technological and Innovation Activities, OECD Publishing, Paris/Eurostat, Luxembourg. https://doi.org/10.1787/9789264304604-en

Perides, M. P. N., de Vasconcellos, E. P. G., \& Vasconcellos, L. (2020). A gestão de mudanças em projetos de transformação digital: estudo de caso em uma organização financeira. Revista de Gestão e Projetos, 11(1), 54-73. https://periodicos.uninove.br/gep/article/download/16087/8126

PessalI, H., \& Fernández, R. (2006). Inovação e teorias da firma. Economia da inovação tecnológica. Campinas, SP: Hucitec.

Quandt, C. O., Silva, H. D. F. N., Ferraresi, A. A., \& Frega, J. R. (2014). Programas de gestão de ideias e inovação: as práticas das grandes empresas na região sul do Brasil. RAI Revista de Administração e Inovação, 11(3), 176-199. https://doi.org/10.11606/rai.v11i3.100220

Sabri, Y., Micheli, G. J., \& Nuur, C. (2018). Exploring the impact of innovation implementation on supply chain configuration. Journal of Engineering and Technology Management, 49, 60- 75. https://doi.org/10.1016/j.jengtecman.2018.06.001

Sacramento, P. M., \& Teixeira, R. M. (2014). Implementação de ações inovadoras e empreendedorismo: Estudo de múltiplos casos em empresas hoteleiras de pequenoporte. Caderno Virtual de Turismo, 14(2). http://www.ivt.coppe.ufrj.br/caderno/index.php/caderno/article/viewFile/874/398

Sampieri, R. H., \& Collado, C. F. Lucio. MPB (2013). Metodologia de pesquisa. Porto Alegre, RS: Penso. http://repositorio.unicentro.br:8080/jspui/handle/123456789/1279

Sarkar, S., \& Carvalho, L. (2006). Inovação no sector dos serviços: uma nova área de investigação. Tourism \& Management Studies, 2, 52-59. https://www.researchgate.net/profile/Luisa-Carvalho10/publication/277215911_Inovacao_no_Sector_dos_Servicos_Uma_Nova_Area_de_ 
Investigacao/links/57cd8aed08aed67896ffb898/Inovacao-no-Sector-dos-ServicosUma-Nova-Area-de-Investigacao.pdf

Seshadri, D. V. R., \& Tripathy, A. (2006). Innovation through intrapreneurship: The road less travelled. Vikalpa, 31(1), 17-30. https://doi.org/10.1177\%2F0256090920060102

Singh, S., Akbani, I., Dhir, S. (2020). Service innovation implementation: a systematic review and research agenda. The Service Industries Journal, 40(7-8), 491-517. https://doi.org/10.1080/02642069.2020.1731477

Snyder, H., Witell, L., Gustafsson, A., Fombelle, P., \& Kristensson, P. (2016). Identifying categories of service innovation: A review and synthesis of the literature. Journal of Business Research, 69(7), 2401-2408. https://doi.org/10.1016/j.jbusres.2016.01.009

Tidd, J., \& Bessant, J. (2015). Gestão da inovação. Porto Alegre, RS: Bookman.

Tigre, P. B. (2014). Gestão da inovação: a economia da tecnologia no Brasil. Rio de Janeiro, RJ: Elsevier. https://adm2016sjcampos.files.wordpress.com/2017/03/gestao-dainovacao-paulo-tigre.pdf

Tushman, M. L. (1977). Special boundary roles in the innovation process. Administrative science quarterly, 22(4), 587-605. https://doi.org/10.2307/2392402

Van Dijk, C., \& Van Den Ende, J. (2002). Suggestion systems: transferring employee creativity into practicable ideas. $R \& D$ Management, 32(5), 387-395.

https://doi.org/10.1111/1467-9310.00270

Yin, R. K. (2017). Case study research and applications: Design and methods. Los Angeles, CA: Sage publications. 